\title{
Formal Institutions and Subjective Well-Being: Revisiting the Cross- Country Evidence
}

\section{Working Paper}

\section{Author(s):}

Bjørnskov, Christian; Dreher, Axel; Fischer, Justina A.V.

Publication date:

2008-04

Permanent link:

https://doi.org/10.3929/ethz-a-005626337

Rights / license:

In Copyright - Non-Commercial Use Permitted

Originally published in:

KOF Working Papers 192 


\section{KOF Working Papers}

Formal Institutions and Subjective Well-Being:

Revisiting the Cross-Country Evidencee

Christian Bjørnskov, Axel Dreher and Justina A.V. Fischer 


\section{KOF}

ETH Zurich

KOF Swiss Economic Institute

WEH D 4

Weinbergstrasse 35

8092 Zurich

Switzerland

Phone +41446324239

Fax +41446321218

www.kof.ethz.ch

kof@kof.ethz.ch 


\title{
Formal Institutions and Subjective Well-Being: \\ Revisiting the Cross-Country Evidence
}

\author{
Christian Bjørnskov $^{*}$, Axel Dreher ${ }^{* *}$ and Justina A.V. Fischer ${ }^{* * *}$
}

April 3, 2008

\begin{abstract}
A long tradition in economics explores the association between the quality of formal institutions and economic performance. The literature on the relationship between such institutions and happiness is, however, rather limited. In this paper, we revisit the findings from recent cross-country studies on the institutions-happiness association. Our findings suggest that the conclusions reached by previous studies are fairly sensitive to the specific measure of 'happiness' used. In addition, the results indicate that the welfare effects of policies may differ across phases of a country's economic development. This bears important policy implications which we discuss in the concluding section of the paper.
\end{abstract}

Keywords: Happiness, institutions, policy implications

JEL codes: I31, H10, H40

Acknowledgments: We thank John Helliwell for sharing his data, Christina Bjerg for excellent research assistance and Niclas Berggren, Kristina Nyström, Jan Ott, seminar participants at the University of Uppsala, the Ratio Institute seminar and the IALMH conference in Padova for helpful comments. Justina AV Fischer acknowledges financing through a Marie Curie Experienced Researcher fellowship.

\footnotetext{
* Department of Economics, Aarhus School of Business, University of Aarhus, Prismet, Silkeborgvej 2, DK-8000 Aarhus C, Denmark; phone: +45 894861 81; e-mail: ChBj@asb.dk.

** ETH Zurich, KOF Swiss Economic Institute, Weinbergstrasse 35, CH-8092, Zurich, Switzerland and CESifo, Germany, E-mail: mail@axel-dreher.de.

*** Department of Economics, Stockholm School of Economics, 65 Sveavägen, 11383 Stockholm, Sweden; e-mail: Justina.Fischer@hhs.se.
} 


\section{Introduction}

Since the study of subjective well-being gained wider interest in the early nineties in both academia and among the public, some countries have gradually begun discussing the maximization of citizens' 'happiness' as a national goal. Even though the field now known as 'happiness studies' has come a long way since its beginnings in psychology, the advent of serious discussions in mainstream politics about including happiness goals in policy evaluations has made the study of potential happiness policies even more urgent (e.g. Layard, 2006).

One of the main questions in this literature is to what extent national institutions affect people's happiness. Institutions, defined broadly by North (1990) as 'the rules of the game', regulate public and private affairs in all modern societies and could thus be expected to exert an important influence on individual well-being. Modern economics and political science assigns 'institutions', both formal and informal, a key role in society, for example by fuelling economic openness and growth and stabilizing liberalization and democracy. ${ }^{1}$ Indeed, the significance of informal institutions such as social trust - unwritten rules, social norms and codes of conduct - is recognized by many studies as a key source of happiness, at least in rich countries (Diener, Diener and Diener, 1995; Uslaner, 2002; Bjørnskov, 2003; Helliwell, 2003, 2006).

However, it seems a priori reasonable to conjecture that the quality of formal institutions of society should also affect the life satisfaction of its citizens. Wellfunctioning legal systems provide and enforce property rights, insuring citizens against violence, theft and economic exploitation, while democratic institutions and political

\footnotetext{
${ }^{1}$ See Zak and Knack (2001), de Haan et al., (2006), Gassebner, Keck and Teh (2006), Aidt and Gassebner (2007), Engerman and Sokoloff (2008), Bjørnskov (2008), and Méon and Sekkat (2008).
} 
decentralization provide everyone with the means to influence the political process (Bjørnskov, Dreher and Fischer, 2008a, 2008b; Dorn et al., 2007, 2008, Fischer, 2008a). However minute such influences may seem on policy outcomes, good institutions also create 'procedural utility', with the potential consequence that people may tolerate even substantial violations of their rights as long as public institutions treat them in a fair manner after such incidents (Stutzer and Frey, 2003; Frey and Stutzer, 2005). ${ }^{2}$ In addition, formal institutions could affect happiness indirectly by giving rise to other factors associated with happiness.

Yet, whether the quality of formal institutions is actually associated with national happiness remains an empirical question without a clear answer, as previous studies find opposing results (cf. Helliwell, 2006; Ovaska and Takashima, 2006; Bjørnskov, Dreher and Fischer, 2008a; Dorn et al., 2007). Many factors could contribute to the empirical confusion. First, neither happiness nor institutional quality is easily measured, and most existing indicators are arguably imprecise. Second, there is the potential of committing an ecological fallacy by drawing cross-level inferences (Manski, 2000; Manski and Cho, 2008). From using purely aggregate cross-country indicators false implications might be drawn for single individuals living in those countries (Robinson, 1950). On the other hand, environmental factors can often play important roles that are not captured in purely individual-level studies (Pearce, 2000). And third, there seem to be no good theoretical or intuitive reasons to assume that the same model applies to poor and rich countries, which most of the literature implicitly does.

\footnotetext{
${ }^{2}$ Moreover, informal institutions such as social trust - the belief that most people can be trusted to follow common societal norms - as well as other types of social capital can arguably also contribute to creating a safe and fulfilling social environment (cf. Uslaner, 2002; Helliwell, 2006).
} 
This paper addresses the question of the potential influence of formal institutions. Using a set of potential macro-level determinants of national happiness derived from previous studies, we test the association between these, a set of different indicators of institutional quality, and national happiness. We test the robustness of our results employing various alternative measures of life satisfaction, based on two recent studies (Helliwell, 2006; Bjørnskov, Dreher and Fischer, 2008a). The results show some support for the importance of institutional quality on happiness. They are, however, not completely robust to how aggregate life satisfaction is defined. More detailed analysis points to a differential role of economic as compared to political institutions in the course of overall societal development. These differences might partly explain the contradictory results of previous studies neglecting these interactions.

\section{Happiness and institutional quality}

The study of happiness and life satisfaction has explored a very large range of potentially determining factors at both the micro, meso and macro level. Quite often, the findings have been contradictory and even when not, the results of the literature can be puzzling in the light of existing theory in economics and political science, and of common sense. The potential influence of formal institutions on average levels of happiness in different countries has been explored in a number of previous studies, and of the myriad of formal institutions that could in principle affect people's well-being, the following have been particularly in the focus of previous research: the presence of democratic institutions and civil liberties, the quality of legal institutions and the rule of law, government effectiveness and economic freedom, alongside with political 
constraints at the federal level such as bicameralism, subsidiarity in political decisionmaking and spending decentralization.

According to Frey and Stutzer (2000a, 934), "extended individual participation possibilities in the form of initiatives and referenda" in Swiss cantons contribute to individual happiness in Switzerland. These results, however, seem not to be robust to changes in the specification of the model. Specifically, the existence of institutions of direct democracy in Swiss cantons has been shown to proxy for the differences in happiness between the country's ethnic groups (Dorn et al., 2008). As Dorn et al. (2007, 517) show for a sample of mostly OECD countries, more political rights "lead to procedures and policies that correspond more closely to voters' preferences and thus increase people's happiness." In contrast, the recent multi-level study in Bjørnskov, Dreher and Fischer (2008a) finds no robust association between the extent of democratic rights or civil liberties and individual life satisfaction. Instead, the results by Dorn et al. (2008) demonstrate the importance of cultural factors to individuals' happiness and individuals' perception of how they benefit from formal institutions.

Arguably, the differential outcomes of those previous studies might to some extent be caused by their focus on different country samples. ${ }^{3}$ More specifically, the level of economic development of the countries in those samples might drive the results. We return to this later.

Turning to the effects of institutional quality and the rule of law, the recent crosscountry studies by Helliwell (2006), Helliwell and Huang (2006) and Ovaska and Takashima (2006) show rather clear support for positive effects of institutional quality,

\footnotetext{
${ }^{3}$ For example, Dorn et al. (2007) use the 1998 ISSP data set with 26 mostly OECD countries while Bjørnskov, Dreher and Fischer (2008a) employ data from a world sample 66 countries of the WVS.
} 
and Fischer (2008a) finds that a stronger rule of law prevents market competition from reducing happiness. On the other hand, Bjørnskov, Dreher and Fischer (2008a) find almost no association between institutional quality and individual happiness in a crosssection of about 66'000 individuals from 66 countries. Again, the differences might be driven by either a (top-down or bottom-up) ecological fallacy in either of these studies, omitted variable biases or the different choice of sample.

In a related area, the extent of constraints on politics, and the strength of political veto players may equally affect people's happiness. A common argument is that most people are status-quo biased, and that the presence of such constraints slows down the reform process (Alt and Lowry, 1994; Tsebelis, 1995) ${ }^{4}$ and, thus, increases well-being of the average risk-averse individual (Bjørnskov, Dreher and Fischer, 2008a, 2008b). The traditional argument, however, derives the welfare benefits of political constraints from the fact that they prevent the 'tyranny of the majority' (Koenig, 2001). Indeed, the results of Henisz $(2000,2002)$ indicate that constraints on policy-making are associated with objectively better economic outcomes.

Often, the presence of veto players is directly linked to formal institutions that relate to the organization of government in a (potentially) multi-tier political system. More specifically, decentralized political-decision making and government spending structures may introduce potential veto-players across tiers, often alongside shared political power at the federal level. Indeed, a direct beneficial impact of fiscal decentralization (but not of political autonomy) was identified in Bjørnskov, Dreher,

\footnotetext{
4 "For the initiator [of a new system] has the enmity of all who would profit by the preservation of the old institution and merely lukewarm defenders in those who would gain by the new ones", Machiavelli, The Prince, 1513, cited in Feinberg (2006).
} 
and Fischer (2008b), while using the same data Bjørnskov, Dreher, and Fischer (2008a) find that bicameral systems - which increase the number of veto-players in the federal legislature - improve individuals' satisfaction with their lives.

In addition, the aggregate cross-country studies by Helliwell (2006) and Ovaska and Takashima (2006) - one stressing government effectiveness, the other economic freedom - also suggest a clear positive impact of the quality of these two formal institutions on well-being. In contrast, the multi-level Extreme Bounds Analysis in Bjørnskov, Dreher and Fischer (2008a) shows very little support for any effects, positive or negative, of these two types of formal institutions. Additional cross-country findings in Bjørnskov, Dreher and Fischer (2007) also indicate no impact of government effectiveness per se on average happiness. However, all of these studies assume that its effects are homogenous across developed and developing countries - an assumption that may not be born out in reality and could be responsible for the confusing findings. Helliwell and Huang (2006) provide a first indication that this may be the case, as they interpret their findings to imply that honest and efficient public service provision increases happiness in relatively poor countries while political and electoral institutions are positively related to happiness in relatively rich countries.

In general, the findings of these aforementioned studies vary considerably, but are also virtually impossible to compare and to assess as they vary in (1) their sample sizes relying on different data sources (World Values Survey sample versus well-developed countries covered by the ISSP), (2) their definitions of happiness measures (aggregate averages, aggregated top three categories versus average individual), and (3) levels of analysis (macro-level versus combined macro- and micro-level). 
This paper tries to remedy some of these shortcomings by: (1) employing the widest range of countries possible, combining several data sources from different geographical regions that also include the often underrepresented African countries; (2) analyzing subsamples identifying differential impacts by levels of economic development; and (3) using two distinct measures of aggregate happiness, one reflecting averages in the population, the other relating to the three top tiers of happy people on a 10-point scale. ${ }^{5}$

\section{Data}

In our attempt at resolving this issue, we draw aggregate data from a number of sources. To measure national average life satisfaction, we employ two different indicators, both based on the survey question "All things considered, how satisfied are you with your life as a whole these days?", which respondents answer on a ten-point scale. The life satisfaction scores employed here are taken from all the four available waves of the World Values Survey (WVS, 2004), a repeated cross-section with a growing number of participating countries. ${ }^{6}$ For the first measure of happiness, we follow Helliwell (2006) and the approach in the World Database of Happiness in using the average national score on the life satisfaction question. As an alternative, we follow the World Values Survey codebook in using the percentage of the population answering in the top three categories, which arguably makes the measure less sensitive to cultural differences in

\footnotetext{
${ }^{5}$ What, however, this paper is not trying to resolve is the ecological fallacy problem that might arise from aggregating individual-level information (Robinson, 1950), as we analyze country-level data. Arguably, a country-level approach might well reveal the importance of population-level characteristics that might be disguised in a purely micro-level study (Pearce 2000).

${ }^{6}$ First wave: 1981-1984, second wave: 1989-1993 third wave: 1994-1999, fourth wave: 1999-2004.
} 
answering at the extremes of the scale (cf. Bjørnskov, 2006; Bjørnskov, Dreher and Fischer, 2007). While the correlation between the two measures is .94, it is worth noting that the country rankings change slightly between the measures. ${ }^{7}$ The average measure is clearly more sensitive to respondents in the thinner tail of the happiness distribution, namely to low ranges of the life satisfaction score, but also to those in the middle and thus gives a good overall assessment of national happiness. On the other hand, using the WVS coding mitigates cultural differences in response styles that may introduce unnecessary noise when using average happiness (cf. Bjørnskov, 2006).

To test for the impact of the quality of formal institutions on life satisfaction, we employ a set of alternative governance measures: 1) the 'legal quality' index from the Fraser Institute (Gwartney and Lawson, 2005); 2) the combined Gastil index of civil liberties and political rights from Freedom House (2005); 3) the Polity IV index of democracy from Marshall and Jaggers (2002); 4)-5) Helliwell's (2006, C43 and 6-8) two groups of variables relating to "the honesty and efficiency of government" and "the operation of the democratic process," which may be viewed as proxy of democratic

\footnotetext{
${ }^{7}$ One could well suspect that any results obtained with a national measure of happiness are contaminated by strong individual-level effects, thus giving rise to an ecological fallacy as discussed in section 2 . However, one can calculate the country fixed effects from running an individual-level ordered probit regression (see Bjørnskov, Dreher and Fischer, 2008a). Comparing the fixed effects coefficients resulting from correcting for robust individual-level determinants of well-being with the simple national measures used here suggests that an ecological fallacy is not likely to be a problem, as the correlations between these coefficients and the two measures are .99 and .92 for the simple average and the top three coding, respectively.
} 
rights; ${ }^{8}$ and 6)-8) three indices from Henisz (2000, 2002), the first measuring the extent of constraints on policy-making, the second measuring the strength of political veto players, and the third capturing the extent of 'law and order'. The eight institutional measures are summarized in Table 1.

\section{[Insert Table 1 about here]}

While two of our indices ('legal quality', 'law and order') capture the protection of property rights, the Gastil index measures the protection of political rights and civil liberties more broadly. They also capture the freedoms of speech and of association, while citizens' political rights in a narrow sense are reflected in the Polity IV index. The remaining indices are designed to measure either government effectiveness or the degree of discretion in policy-making. By testing these indicators against each other, we hope to be able to evaluate which elements of governance are responsible for potential consequences on national average happiness.

In choosing our control variables, we take the specification in Helliwell (2006) as a starting point and supplement it by additional aggregate variables found to be important determinants of well-being in Bjørnskov, Dreher and Fischer (2007).

\footnotetext{
${ }^{8}$ These variables derive from Kaufmann et al. (2003), with the first variable being the average of government effectiveness, regulatory efficiency, rule of law and lack of corruption, and the second variable the average of voice and accountability, and political stability. It nevertheless remains unclear how Helliwell arrives at measures for 1990 and 1981, as the Kaufmann dataset only starts in 1996. These two highly correlated indices are also used in Helliwell and Huang's (2006) attempt at identifying differential effects in rich and poor countries.
} 
Descriptive statistics of all variables are shown in Table 2 while sources are given in the appendix.

\section{[Insert Table 2 about here]}

We include indicators of two dimensions of social capital: the average number of memberships in nine different types of voluntary organizations, which in the tradition of Putnam (2000) aims to capture social activity and social networks; and social trust - an indicator of honesty and trustworthiness - which is measured by the percentage of respondents answering yes to the question "In general, do you think most people can be trusted?" Following Helliwell (2006), our baseline also includes measures of how strongly people believe in god (measured by the national percentage answering 'yes' to the question "Do you believe in a superior being"), the divorce rate and the official unemployment rate. This gives us a maximum sample of 136 pooled country-year observations from 55 countries potentially observed in either waves, namely in 1981, 1990, 1995 and 1999, for which we have full data. ${ }^{9}$ All countries are listed in Appendix Table A2.

The baseline model is supplemented by a set of additional variables in a series of steps. First, we include period fixed effects to take care of joint trends over time and of

\footnotetext{
${ }^{9}$ As such, we estimate an unbalanced panel, not a cross-section. As happiness and institutions change slowly over time, inclusion of country fixed effects is not advisable. It may be argued that pooling the data artificially increases the number of observations. Furthermore, the unbalanced structure of the data gives some countries greater weight in the estimates than others. However, the main results remain when we weigh observations giving each country equal weight. They also remain when we use the 1999 crosssection only.
} 
the changing country composition of the sample across waves. Second, we include dummies for postcommunist countries, Latin America and Asia, which previous research shows to be highly significant (Bjørnskov, Dreher and Fischer, 2007, 2008a). Third, we include openness to trade and the investment price level relative to the US, both of which are measures of international integration and business prospects and are robustly positively associated with happiness according to recent studies (Bjørnskov, Dreher and Fischer, 2007, 2008a). ${ }^{10}$

In the following, we test for the influence of the institutional indicators using OLS. In order to test for the sensitivity of the results to the potential influence of single outlying observations, we supplement the OLS results with estimates obtained by a robust regression technique, which iteratively assigns smaller weights to the observations with larger deviations of their absolute residuals from the median residual. Finally, for testing the dependence of potential institutional impacts on the stage of economic development, we also use a reduced sample of country observations with an average GDP per capita above 8000 purchasing-power parity adjusted US dollars for which 80 country-year observations from 31 countries are available. The choice of a threshold level of 8000 USD may be considered 'natural' as it is approximately the level at which most studies find average income to cease being associated with subjective well-being. All results are reported for both happiness measures using the full sample and the reduced sample of rich countries.

\footnotetext{
10 Bjørnskov, Dreher and Fischer (2008a) find additional robust determinants of life satisfaction. However, not all are significant in this sample and others are only available for a small number of observations. We therefore do not include these variables in the full specification, but note that the results reported below remain unchanged if adding the additional variables.
} 


\section{Results}

As a first simple way of illustrating the potential effects of institutional quality on life satisfaction, Table 3 reports the correlations between the institutional variables as well as their correlations with the two measures of happiness. First of all, the table illustrates the difficulty in separating different institutional characteristics, as most indices are highly related. The relative exceptions are the Polity IV index and the two political constraints indicators that are more moderately correlated to the remaining institutional indices. However, it is worth noting that most rich countries score a perfect 10 on the Polity IV index, which is therefore effectively right-censored. ${ }^{11}$ Second, the table also shows that restricting the sample to only relatively rich countries reduces some of the correlations and thus makes it potentially easier to separate the effects of single institutions on happiness.

\section{[Insert Table 3 about here]}

\subsection{Are formal institutions associated with happiness?}

Table 4, column 1 first replicates Helliwell's (2006) results using the 'honest and efficient government' indicator and his original specification with average national happiness as dependent variable, whereas the same column in Table 5 instead reports the results of using the share of respondents in the top three categories, i.e., the coding used by the World Values Survey (WVS) of the life satisfaction questions. As the

\footnotetext{
${ }^{11}$ It is also well known that countries tend to fair better on the Polity IV index of democracy than on the alternative Gastil index of political rights and civil liberties or Henisz's (2000) measures. The reason is that the latter two indices apply a broader concept of democracy that also entails civil rights, as explained in the previous section.
} 
estimates show, the existence of social networks increases happiness at the ten percent level of significance at least. At the one percent level, social trust, and believing in god increase average and 'top three' well-being, while divorce and unemployment rates reduce well-being. Our variable of main interest, government efficiency, increases happiness, with a coefficient significant at the one percent level.

A series of model extensions, as described before, are reported in columns 2-6 of both tables. Although the results pertaining to the control variables overall remain qualitatively similar across our models, a few notable differences pertain. ${ }^{12}$ First, the effects of memberships are not robust to using the top three tier life satisfaction scores when adding the control variables from Bjørnskov, Dreher and Fischer (2007) or, for both happiness measures alike, when restricting the sample to only rich countries in column 6. On the other hand, the other dimension of social capital - social trust - is strongly significant throughout. Second, the effects of divorce rates only show up robustly when using the average coding while, on the reverse, the effects of unemployment are only robust for the top three tier measure.

[Insert Table 4 about here]

[Insert Table 5 about here]

\footnotetext{
${ }^{12}$ As the table shows, the introduction of regional dummies substantially improves the statistical fit. With respect to these variables, it is worth mentioning that people in Latin American countries, in particular, are happier than average. The difference to the rest of the world, all other things being equal, is +0.44 points on the average measure and +5.6 percentage points, when using the WVS coding.
} 
Turning to the effects of honest and efficient governments, we basically replicate Helliwell's (2006) main findings. The results in both tables nevertheless indicate that the simple model in columns 1-3 may tend to overestimate the effects of formal institutions. When employing the WVS coding of life satisfaction, honest and efficient government just fails statistical significance in the sample of rich countries in column 6 of Table 4. Overall, there hence seems to be some support for the influence of institutional quality on happiness. Previous studies may nevertheless have overstated this effect. Calculating elasticities, the results show that the beta drops from .39 to .19 when including additional, relevant, control variables.

Moreover, the results in Tables 4 and 5 do not inform about which type of formal institutions matters. Given the rather strong correlations between various measures of governance, it is not obvious which type of formal institutions matters as one indicator might proxy for another. In addition, the differences across the two codings of life satisfaction also reveal (by calculating betas) that formal institutional quality as measured by 'honest and efficient government' is relatively more important with the average scores while informal institutions, measured by social trust, are the more important dimension when using the top three-tier WVS coding.

\section{[Insert Table 6 about here]}

Table 6 - employing the baseline of column 5 in the previous tables - tests the potential importance of the broader number of alternative institutional indicators as used in the previous literature and summarized in Table 1. The table first shows support for legal quality from the Fraser Institute as a determinant of happiness. This is also 
reflected in the significance of the Gastil index across columns, although the effects are substantially larger for the sample of only rich countries. Using the Polity IV index, which more narrowly captures the importance of democratic political institutions as opposed to market and judicial institutions, reveals a more mixed picture. Here, the index is only significant in the sample of rich countries. These results are reflected in the following panels, where Helliwell's (2006) democracy index and Henisz's (2000, 2002) two measures of political constraints follow the structure of the Gastil index. In the last panel, the evidence for Henisz's law and order index, on the other hand, is rather weak.

Without wanting to overstate the differences, it consequently seems that the quality of formal institutions that relate to free markets and judicial impartiality matter in the full sample - the largest beta is that of legal quality, which is .36 - while the effect of indicators that are more likely to include components of political institutions and participation rights tends to matter as much in the sample of rich countries where the betas of the Gastil index and democratic process also reach .3 to .4 . Due to the high interrelatedness of the measures, the robustness of any single finding is nevertheless uncertain.

Table 7 therefore summarizes the results of testing the strength of the institutional indicators against each other. For all eight indices, respectively, one additional index of the seven remaining ones was added and the table reports the number of instances out of seven in which the index remains significant at conventional levels of significance. As such, the results in absolute numbers can indicate the relative strength of each 
institutional indicator. ${ }^{13}$ For the average life satisfaction measure, legal quality quite clearly dominates in the total sample, never being insignificant at conventional levels. However, quite strong results are also obtained for 'honest and efficient government' (5 times significant out of 7 cases) and Political Constraints V (4 out of 7 cases). For the high-income sample, it is less clear which index dominates as both legal quality, the Gastil index, democratic process and the Political Constraints $\mathrm{V}$ measure remain significant in all cases.

When using the WVS coding of the life satisfaction question instead, results change somewhat even though the two types of coding result in very similar country rankings and highly correlated scores. Of all eight indices, only legal quality does consistently well in the total sample. On the other hand, restricting the sample to rich and middle-income countries shows that the Gastil index and Political Constraints V remain significant in all cases, while democratic process fails once and legal quality, the Polity IV index and Political Constraints III remain significant in five cases.

As such, the evidence remains mixed. First, the robust impact of legal quality across the two different definitions of happiness and the two sample sizes is quite striking. However, for the full sample there are virtually no other robust relations across and within the two happiness measures. On the other hand, the overall picture looks different for the richer countries where both legal quality, the Gastil index, the democratic process measure, and Political Constraints III and V are fairly robust.

\footnotetext{
${ }^{13}$ An important caveat of this exercise is that the measures are correlated. As such, a few results in Table 6 may be potentially misleading as variance inflation factors in roughly a quarter of the cases are close to or above 5 and in a limited number of cases above 10 .
} 
With respect to the Polity IV index and to some extent also the Gastil index, it must be stressed that there is rather little variation in these indices at the top of the global income distribution. As such, their profiles tend to follow the pattern of the effects of economic development on happiness. In other words, the specific relation between these indices and GDP per capita implies that they are relatively likely to pick up the non-linear relation between average income and happiness documented in other studies (cf. Schyns, 1998). Seen in light of this feature, the relative strength of the Gastil index may be more remarkable while also being less reliable since it measures the status of both economic-judicial and political institutions. ${ }^{14}$

\section{[Insert Table 7 about here]}

\subsection{Splitting economic-judicial and political institutions}

As the results in Table 7 thus suggest, it is almost impossible to separate the effects of different types of formal institutions on happiness since they are highly correlated and strongly related to economic development. In addition to the standard analysis we therefore perform the following simple three-step test: 1) we calculate the residuals of regressing the eight indicators on (log) GDP per capita, thereby taking out most joint variation due to economic development; 2) we use these residuals as if they were precise measures of institutions in a principal components analysis (Table A3 in the

\footnotetext{
${ }^{14}$ Indeed, splitting the Gastil index in political rights and civil liberties shows that the variation of the full index across the richer countries is driven by the second component, mirroring the invariance of the more narrowly defined Polity IV index (see Fischer, 2008b).
} 
appendix reports the specifics of this analysis); and 3) we rerun the analyses above using the component solution of the analysis.

First of all, the principal components analysis supports the existence of two orthogonal components that can be readily interpreted as a political institutions component and a component capturing the quality of economic and judicial institutions (see Table A3); as such, the results are broadly consistent with the similar analysis in Munck and Verkuilen (2002). Using these two scores - which we term 'political factor' and 'economic factor' - in place of the primary indices therefore should provide more precise information on the importance of the two separate types for happiness than the analyses above. As Table 8 shows, with some qualifications, this actually is the case.

\section{[Insert Table 8 about here]}

Starting with the findings for average happiness in the full sample, the results in column 1 only support an effect of the economic-judicial institutions as the coefficient on the political factor score is insignificant and virtually zero. On the other hand, none of the factors are significant in column 3 where we use the WVS coding. However, when restricting the sample to including only middle- and high-income countries, the picture changes. For either measure of life satisfaction, the political dimension of institutions clearly dominates, while the economic factor remains insignificant. In other words, our results indicate that whenever countries have reached a certain level of economic development, the development of a democracy may be beneficial for overall national happiness while the development of factors such as a fair and efficient legal 
system affects the concerns of citizens in all countries, rich and poor, alike. ${ }^{15}$ Our findings thus suggest that the importance of institutional types may change over the course of overall development. The last section summarizes and discusses the significance of the full set of findings.

\section{Conclusions and policy implications}

What creates happiness and whether national happiness can be affected has been a key topic in recent years in the new literature on happiness. However, many empirical findings have been conflicting, not least those pertaining to the potential influence of institutional quality. This paper has looked closer into the association between the quality of formal institutions and national happiness, paying attention to different types and different indicators. Particularly, we have estimated the potential influence of formal institutions by employing eight different indicators of institutional quality and governance that augment a standard baseline specification.

Overall, our results support the existence of a positive and significant effect of institutions on average national happiness. However, some measures are clearly stronger than others, and in particular the arguably cleanest measure of democracy - the Polity IV index - is questionable in the full sample while a measure of legal quality from the Fraser Institute does quite well in all analyses. The results also illustrate the difficulty in separating different types and dimensions of institutional quality, as well as measuring such factors with precision. The high correlations between institutional indicators make

\footnotetext{
${ }^{15}$ It should be stressed that while the coefficient of the political factor seems much larger in the sample of rich countries than the coefficient of the economic factor in the full sample, the quantitative difference when calculating beta coefficients turns out to be marginal.
} 
strong specification tests between indicators infeasible, forcing us to rely on weaker tests to assess which institutions are likely to matter more. This problem is only exacerbated in the subsample in which we delete the poorest countries, as only one very rich country - Singapore - stands out as being undemocratic. As such, the results pertaining to purely political institutions can easily be questioned as in the academic discussion between those claiming the existence of an effect of democracy on happiness (cf. Frey and Stutzer, 2000; Helliwell and Huang, 2006) and those arguing against (Dorn et al., 2008).

Yet, creating two artificial measures of institutions employing factor analysis provides some support for the existence of independent effects of overall economicjudicial and political institutions. The first type seems to dominate the second when a sufficient number of developing countries enter the sample, while analyses restricted to middle- and high-income countries show an additional strong support for a beneficial effect of the latter type of institutions. This finding is in line with Dorn et al. (2007), who also show that democracy increases happiness in a cross-section of richer countries. As such, one could conjecture that the difficulty of obtaining any clear pattern in previous studies may have been because these studies have ignored the specific heterogeneity of the effect among different groups of countries that we find here.

Overall, our findings indicate a real and positive association between the overall quality of formal institutions and national happiness, but given available measures of such features, it is difficult to differentiate the effects of particular types of institutions. However, our results in this paper suggest that citizens may derive subjective well-being from having democratic political institutions whenever the bulk of the population has escaped absolute poverty. Before that goal has been reached, only economic-judicial 
institutions protecting life and property rights contribute to happiness that simultaneously may also fuel economic growth (cf. Knack and Keefer, 1995; Berggren, 2003; Engerman and Sokoloff, 2008). As such, we note that part of the controversy in the literature may simply stem from the systematic parameter heterogeneity of the institutional estimates that may have biased full-sample estimates towards zero in most large-sample studies.

A final question to be touched upon is whether our findings hold any policy implications. We explicitly do not discuss whether governments should attempt to follow such implications - a question which Frey and Stutzer (2000b) address at length - only whether the findings hold potential implications.

First, the results indicate that the strength of legal quality is associated with happiness although this association seems stronger when poorer countries enter the sample. One of the potential ways to raise national happiness would thus seem to be to invest in a fair and efficient legal system in poor and middle-income countries, as indicated by Ovaska and Takashima (2006). An additional benefit of such an approach would also be to increase the rate of economic growth as suggested by the vast literature on the topic. However, the everlasting problem remains how to encourage a fair and efficient legal system in which citizens can have confidence.

Second, our findings suggest that democratization would in general be beneficial for national happiness when countries have reached a level of economic development at which most basic needs are met for the majority of the population. However, even if economic development and achieving a basic level of quality of life is an explicit aim of international development aid, the results of that literature show that such efforts are at best ineffective (e.g. Knack, 2004). Instead, the democracy literature suggests that when 
countries reach the cut-off level of 8000 USD employed here, democratization becomes steadily more likely and more stable with additional growth (cf. Lipset, 1959; Paldam, 2007). In addition, Singapore, which is one of the very few rich non-oil countries that has not developed free political rights, does not seem comparatively unhappy. With an average level of 7.2 and 49 percent of respondents in the top three categories, Singapore is roughly on par with Italy and even higher than France. Although democratic rights therefore in general seem to lead to more happiness in richer countries, there are apparently other ways to make citizens fairly happy.

At the end of the day, we are left with a set of findings that entail rather difficult implications. Fair and efficient judicial systems seem to contribute to both happiness and economic development, but the persistent lack of such characteristics in many third world countries also suggests that institutional quality cannot simply be transplanted or copied from other countries. For middle and high-income countries, the existence of democratic political institutions is positively associated with happiness. The restriction of the effect of such institutions in richer countries fortunately represents only a minor problem, as most studies find that democracy tends to emerge when countries reach a certain level of economic development. 
References

Aidt, T.S. and M. Gassebner, 2007, Do Autocratic States Trade Less? Cambridge Working Papers in Economics 0742.

Alt, J. and R. Lowry, 1994, Divided Governments, Fiscal Institutions and Budget Deficits: Evidence from the States, American Political Science Review 88: 811828.

Berggren, N., 2003, The benefits of economic freedom: a survey, The Independent Review 8: 193-211.

Bjørnskov, Ch., 2003, The happy few. Cross-country evidence on social capital and life satisfaction, Kyklos 56: 3-16.

Bjørnskov, Ch., 2006, The multiple facets of social capital, European Journal of Political Economy 22: 22-40.

Bjørnskov, Ch., 2008, Economic growth. Forthcoming in Gert T. Svendsen and Gunnar L.H. Svendsen (eds.), Handbook of Social Capital, London: Edward Elgar.

Bjørnskov, Ch., A. Dreher and J.A.V. Fischer, 2007, The Bigger the Better? Evidence of the Effect of Government Size on Life Satisfaction around the World, Public Choice 130: 267-292.

Bjørnskov, Ch., A. Dreher and J.A.V. Fischer, 2008a, Cross-Country Determinants of Life Satisfaction: Exploring Different Determinants across Groups in Society, Social Choice and Welfare 30: 119-173.

Bjørnskov, Ch., A. Dreher and J.A.V. Fischer, 2008b, On Decentralization and Life Satisfaction, Economics Letters 99: 147-151.

De Haan, J., S. Lundström and J.-E. Sturm, 2006, Market-oriented institutions and policies and economic growth: a critical survey, Journal of Economic Surveys 20: 157-191.

Diener, E., M. Diener and C. Diener, 1995, Factors predicting the subjective well-being of nations, Journal of Personality and Social Psychology 69: 851-864.

Dorn, D., J.A.V. Fischer, G. Kirchgässner and A. Sousa-Poza, 2007, Is it culture or democracy? The impact of culture and democracy on happiness, Social Indicators Research 82: 502-526. 
Dorn, D., J.A.V. Fischer, G. Kirchgässner and A. Sousa-Poza, 2008, Direct democracy and life satisfaction revisited: new evidence for Switzerland, forthcoming in Journal of Happiness Studies.

Engerman, S.L. and K.L. Sokoloff, 2008, Debating the role of Institutions in Political and Economic Development: Theory, History and Findings, Annual Review of Political Science 11: 119-135.

Feinberg, R.E., 2006, Presidential Mandates and Ministerial Institutions: Summitry of the Americas, the Organization of American States (OAS) and the InterAmerican Development Bank (IDB), Review of International Organizations 1, 1: 69-94.

Fischer, J.A.V, 2008a, Competition and well-being: does market competition make people unhappy? Working Paper Series in Economics and Finance 697, Stockholm School of Economics.

Fischer, J.A.V, 2008b, Does procedural fairness matter to subjective well-being? The appeasement effects of democracy on positional concerns, Unpublished manuscript, Stockholm School of Economics.

Freedom House, 2005, Country Rankings, www.freedomhouse.org.

Frey, B.S. and A. Stutzer, 2000, Happiness, economy and institutions, The Economic Journal 110: 918-938.

Frey, B.S. and A. Stutzer, 2000, Maximizing happiness? German Economic Review 1: $145-167$.

Frey, B.S. and A. Stutzer, 2005, Beyond outcomes: measuring procedural utility. Oxford Economic Papers 57: 90-111.

Gassebner, M., A. Keck and R. Teh, 2006, Shaken, Not Stirred: The Impact of Disasters on International Trade, KOF Working Papers No. 139.

Gwartney, J. and R. Lawson, 2005, Economic Freedom of the World 2005, downloadable from http://www.freetheworld.com/download.html

Helliwell, J.F., 2003, How's life? Combining individual and national variables to explain subjective well-being, Economic Modelling 20: 331-360.

Helliwell, J.F, 2006, Well-being, social capital, and public sector; What's new? The Economic Journal 116 (510): C34-C45. 
Helliwell, J.F. and W. Huang, 2006, How's your government? International evidence linking good government and well-being, NBER working paper 11988.

Henisz, W.J., 2000, The institutional environment for economic growth, Economics \& Politics 12: 1-31.

Henisz, W.J., 2002, The institutional environment for infrastructure investment, Industrial and Corporate Change 11, 2, REF.

Heston, A., R. Summers and B. Aten, 2002, Penn World Tables, Version 6.1, Center for International Comparisons (CICUP), University of Pennsylvania, October, 2002.

Kaufmann, D., A. Kraay and M. Mastruzzi, 2003, Governance matters III: Governance indicators for 1996-2002, World Bank Policy Research Working Paper no. 3106.

Knack, S., 2004, Does foreign aid promote democracy? International Studies Quarterly 48: 251-266.

Knack, S. and P. Keefer, 1995, Institutions and economic performance: cross-country tests using alternative institutional measures, Economics \& Politics 7: 207-227.

König, Th. 2001, Bicameralism and Party Politics in Germany: an Empirical Social Choice Analysis, Political Studies 49: 411-437.

Layard, R., 2006, Happiness and Public Policy: A Challenge to the Profession. Economic Journal 116: C24-33.

Lipset, S.M., 1959. Some social requisites of democracy: Economic development and political legitimacy, American Political Science Review 53: 69-105.

Manski, C., 2000, Economic analysis of social interactions, Journal of Economic Perspectives 14: 115-136.

Manski, C and W. Cho, 2008, Cross Level/Ecological Inference. Chapter 22 in H. Brady, D. Collier, and J. Box-Steffensmeier (eds), Oxford Handbook of Political Methodology. Oxford: Oxford University Press.

Marshall, M. and K. Jaggers, 2002, Polity IV dataset. University of Maryland, Center for International Development and Conflict Management.

Méon, P.-G. and K. Sekkat, 2008, Institutional Quality and Trade: Which Institutions? Which Trade? Economic Inquiry, forthcoming.

Munck, G.L. and J. Verkuilen, 2002, Conceptualizing and Measuring Democracy: Evaluating Alternative Ideas, Comparative Political Studies 35, 1: 5-34. 
North, D.C., 1990, Institutions, Institutional Change, and Economic Performance. Cambridge: Cambridge University Press.

Ovaska, T. and R. Takashima, 2006, Economic Policy and the Level of Self-Perceived Well-Being: An International Comparison, Journal of Socio-Economics 35: 308325.

Paldam, M., 2007, The Big Pattern of Democracy. Pp. 103-129 in A. Marciano and JM. Josselin (eds.), Democracy, Freedom and Coercion: A Law and Economics Approach. Cheltenham: Edward Elgar.

Pearce, N., 2000, The ecological fallacy strikes back, Journal of Epidemiology and Community Health 54: 326-327.

Political Risk Services, 1996, The ICRG Rating System: Political Risk Services.

Putnam, R.D., 2000, Bowling Alone: The Collapse and Revival of American Community. New York: Simon \& Schuster.

Robinson, W.S., 1950, Ecological Correlations and the Behavior of Individuals, American Sociological Review 15: 351-357.

Schyns, P., 1998, Crossnational Differences in happiness: economic and cultural factors explored, Social Indicators Research 43: 3-26.

Stutzer, A., and B.S. Frey, 2003, Institutions Matter for Procedural Utility: An Economic Study of the Impact of Political Participation Possibilities. Pp 81-99 in R. Mudambi, P. Navarra and G. Sobbrio, (eds.), Economic Welfare, International Business and Global Institutional Change. Cheltenham: Edward Elgar.

Tsebelis, G., 1995, Decision Making in Political Systems: Veto Players in Presidentialism, Parliamentarism, Multicameralism and Multipartyism, British Journal of Political Science 25: 289-325.

Uslaner, E.M., 2002, The Moral Foundations of Trust. Cambridge, UK: Cambridge University Press.

World Bank, 2007, World Development Indicators, CD-Rom, Washington, D.C.

World Values Survey, 2006, European and World values surveys four-wave integrated data file, 1981-2004, v.20060423. The European Values Study Foundation and World Values Survey Association, available at http://www.worldvaluessurvey.org/ . 
Zak, P. and S. Knack, 2001, Trust and Growth, Economic Journal 111: 295-321. 
Table 1. Institutional measures

\begin{tabular}{|c|c|c|}
\hline Name & Source & Description \\
\hline Legal quality & $\begin{array}{l}\text { Fraser } \\
\text { Institute } \\
\text { (Gwartney } \\
\text { and Lawson, } \\
\text { 2005) }\end{array}$ & $\begin{array}{l}\text { Overall measure of the quality and capacity of the legal system, } \\
\text { consisting of indices of judicial independence, impartiality of the } \\
\text { courts, protection of intellectual property rights, military } \\
\text { interference in law and politics, and integrity of the legal system. }\end{array}$ \\
\hline Gastil index & $\begin{array}{l}\text { Freedom } \\
\text { House } \\
(2005)\end{array}$ & $\begin{array}{l}\text { Index capturing the existence of political rights and civil liberties; } \\
\text { lower scores mean better protection of rights and liberties. }\end{array}$ \\
\hline Polity IV index & $\begin{array}{l}\text { Marshall and } \\
\text { Jaggers } \\
(2002)\end{array}$ & $\begin{array}{l}\text { Index intended to capture three essential elements of democracy: 1) } \\
\text { institutions and procedures enabling citizens to freely express their } \\
\text { preferences for policies and leaders; 2) effective constraints on the } \\
\text { exercise of power by the executive; and 3) the civil liberties of } \\
\text { citizens to participate in the political process. }\end{array}$ \\
\hline $\begin{array}{l}\text { Honest and } \\
\text { efficient gov. }\end{array}$ & $\begin{array}{l}\text { Helliwell } \\
(2006)\end{array}$ & $\begin{array}{l}\text { Average of rule of law, regulatory quality, bureaucratic efficiency } \\
\text { and control of corruption indices from Kaufmann et al. (2003). }\end{array}$ \\
\hline $\begin{array}{l}\text { Democratic } \\
\text { process }\end{array}$ & $\begin{array}{l}\text { Helliwell } \\
(2006)\end{array}$ & $\begin{array}{l}\text { Average of political stability and voice and accountability indices } \\
\text { from Kaufmann et al. (2003). }\end{array}$ \\
\hline $\begin{array}{l}\text { Political } \\
\text { constraints III }\end{array}$ & $\begin{array}{l}\text { Henisz } \\
(2000,2002)\end{array}$ & $\begin{array}{l}\text { Index capturing constraints on the feasibility of policy change, } \\
\text { defined as the degree to which a change in the preferences of one or } \\
\text { more political actors is permitted to affect government policy. The } \\
\text { index effectively measures the number and strength of political veto } \\
\text { points. }\end{array}$ \\
\hline $\begin{array}{l}\text { Political } \\
\text { constraints V }\end{array}$ & $\begin{array}{l}\text { Henisz } \\
(2000,2002)\end{array}$ & $\begin{array}{l}\text { Index employing the same data and logic as Political constraints III, } \\
\text { but adding veto points within the judiciary and sub-federal entities. }\end{array}$ \\
\hline Law and order & $\begin{array}{l}\text { Henisz } \\
(2000,2002)\end{array}$ & $\begin{array}{l}\text { Law and Order index from Political Risk Services (1996). Higher } \\
\text { scores imply "a strong law and order tradition;" lower score mean "a } \\
\text { tradition of depending on physical force or illegal means to setting } \\
\text { claims." }\end{array}$ \\
\hline
\end{tabular}


Table 2. Descriptive statistics

\begin{tabular}{lccc}
\hline & Mean & Standard deviation & Observations \\
\hline Life satisfaction, average & 6.867 & 1.089 & 136 \\
Life satisfaction, top three & 46.981 & 19.159 & 130 \\
Average memberships & .422 & .322 & 136 \\
Social trust & .326 & .144 & 136 \\
Belief in god & .346 & .239 & 136 \\
Divorce rate & 1.909 & 1.218 & 136 \\
Unemployment rate & 8.001 & 4.651 & 136 \\
Postcommunist & .301 & .461 & 136 \\
Openness to trade & 63.652 & 47.804 & 122 \\
Investment price level & .864 & .294 & 122 \\
GDP per capita & 13,157 & 6,866 & 122 \\
& & & \\
Legal quality & 7.089 & 1.627 & 116 \\
Gastil index & 2.199 & 1.509 & 126 \\
Polity IV index & 7.139 & 4.695 & 127 \\
Honest and efficient government & .913 & .954 & 136 \\
Democratic process & .913 & .954 & 136 \\
Political contraints III & .409 & .181 & 129 \\
Political contraints V & .654 & .252 & 128 \\
Law and order & 4.823 & 1.169 & 124 \\
\hline
\end{tabular}


Table 3. Correlations between life satisfaction and institutional measures

\begin{tabular}{|c|c|c|c|c|c|c|c|c|}
\hline & 1 & 2 & 3 & 4 & 5 & 6 & 7 & 8 \\
\hline 1. Honest and efficient government & 1 & $\begin{array}{c}.92 \\
(.89)\end{array}$ & $\begin{array}{c}.83 \\
(.74)\end{array}$ & $\begin{array}{c}-.73 \\
(-.66)\end{array}$ & $\begin{array}{c}.58 \\
(.51)\end{array}$ & $\begin{array}{c}.45 \\
(.48)\end{array}$ & $\begin{array}{c}.61 \\
(.61)\end{array}$ & $\begin{array}{c}.74 \\
(.69)\end{array}$ \\
\hline 2. Democratic process & & 1 & $\begin{array}{c}.83 \\
(.77)\end{array}$ & $\begin{array}{l}-.79 \\
(-.76)\end{array}$ & $\begin{array}{c}.65 \\
(.61)\end{array}$ & $\begin{array}{c}.54 \\
(.57)\end{array}$ & $\begin{array}{c}.72 \\
(.69)\end{array}$ & $\begin{array}{c}.75 \\
(.68)\end{array}$ \\
\hline 3. Legal quality & & & 1 & $\begin{array}{l}-.62 \\
(-.51)\end{array}$ & $\begin{array}{c}.48 \\
(.44)\end{array}$ & $\begin{array}{c}.35 \\
(.37)\end{array}$ & $\begin{array}{c}.61 \\
(.66)\end{array}$ & $\begin{array}{l}.77 \\
(. .73)\end{array}$ \\
\hline 4. Gastil index & & & & 1 & $\begin{array}{l}-.94 \\
(-.94)\end{array}$ & $\begin{array}{l}-.64 \\
(-.69)\end{array}$ & $\begin{array}{l}-.76 \\
(-.65)\end{array}$ & $\begin{array}{l}-.61 \\
(-.48)\end{array}$ \\
\hline 5. Polity IV index & & & & & 1 & $\begin{array}{c}.65 \\
(.72)\end{array}$ & $\begin{array}{c}.74 \\
(.63)\end{array}$ & $\begin{array}{c}.52 \\
(.41)\end{array}$ \\
\hline 6. Political contraints III & & & & & & 1 & $\begin{array}{c}.77 \\
(.75)\end{array}$ & $\begin{array}{c}.34 \\
(.44)\end{array}$ \\
\hline 7. Political contraints $\mathrm{V}$ & & & & & & & 1 & $\begin{array}{c}.62 \\
(.64)\end{array}$ \\
\hline 8. Law and order & & & & & & & & 1 \\
\hline Average & .75 & .64 & .55 & -.51 & .36 & .33 & .42 & .49 \\
\hline Top three & .72 & .62 & .49 & -.52 & .40 & .36 & .39 & .48 \\
\hline
\end{tabular}


Table 4. Basic results, "average" coding

\begin{tabular}{|c|c|c|c|c|c|c|}
\hline Dependent & 1 & 2 & 3 & 4 & 5 & 6 \\
\hline Average & $.346^{* * *}$ & $.229 * *$ & $.346^{* * *}$ & $.406 * * *$ & $.406^{* * *}$ & .262 \\
\hline memberships & $(.127)$ & $(.099)$ & $(.133)$ & $(.167)$ & $(.152)$ & $(.197)$ \\
\hline Social trust & $\begin{array}{c}1.895 * * * \\
(.444)\end{array}$ & $\begin{array}{c}1.409 * * * \\
(.363)\end{array}$ & $\begin{array}{c}1.367 * * * \\
(.379)\end{array}$ & $\begin{array}{c}1.445^{* * *} \\
(.459)\end{array}$ & $\begin{array}{c}1.127 * * * \\
(.406)\end{array}$ & $\begin{array}{c}1.266^{* * *} \\
(.455)\end{array}$ \\
\hline Belief in god & $\begin{array}{l}1.746 * * * \\
(.250)\end{array}$ & $\begin{array}{l}.753 * * * \\
(.235)\end{array}$ & $\begin{array}{c}.691 * * * \\
(.245)\end{array}$ & $\begin{array}{l}.874 * * * \\
(.292)\end{array}$ & $\begin{array}{l}.974 * * * \\
(.241)\end{array}$ & $\begin{array}{c}.854 * * * \\
(.246)\end{array}$ \\
\hline Divorce rate & $\begin{array}{c}-.176^{* * *} \\
(.042)\end{array}$ & $\begin{array}{c}-.106 * * * \\
(.041)\end{array}$ & $\begin{array}{c}-.088 * * \\
(.039)\end{array}$ & $\begin{array}{c}-.099 * * \\
(.039)\end{array}$ & $\begin{array}{l}-.056 \\
(.036)\end{array}$ & $\begin{array}{l}-.039 \\
(.041)\end{array}$ \\
\hline $\begin{array}{l}\text { Unemployment } \\
\text { rate }\end{array}$ & $\begin{array}{c}-.030 * * * \\
(.010)\end{array}$ & $\begin{array}{c}-.024 * * * \\
(.009)\end{array}$ & $\begin{array}{l}-.015 \\
(.009)\end{array}$ & $\begin{array}{l}-.012 \\
(.009)\end{array}$ & $\begin{array}{l}-.008 \\
(.009)\end{array}$ & $\begin{array}{l}.001 \\
(.012)\end{array}$ \\
\hline Honest and & $.780 * * *$ & $.629 * * *$ & $.613 * * *$ & $.404 * * *$ & $.343 * * *$ & $.307 * *$ \\
\hline efficient gov. & $(.071)$ & $(.084)$ & $(.081)$ & $(.109)$ & $(.081)$ & $(.149)$ \\
\hline Postcommunist & & $\begin{array}{c}-.647 * * * \\
(.179)\end{array}$ & $\begin{array}{c}-.626 * * * \\
(.181)\end{array}$ & $\begin{array}{c}-.655 * * * \\
(.251)\end{array}$ & $\begin{array}{c}-.789 * * * \\
(.182)\end{array}$ & $\begin{array}{l}-.197 \\
(.314)\end{array}$ \\
\hline $\begin{array}{l}\text { Openness to } \\
\text { trade }\end{array}$ & & & & $\begin{array}{l}.002 * * \\
(.001)\end{array}$ & $\begin{array}{l}.002 * * \\
(.001)\end{array}$ & $\begin{array}{l}.003 * * \\
(.001)\end{array}$ \\
\hline $\begin{array}{l}\text { Investment } \\
\text { price level }\end{array}$ & & & & $\begin{array}{l}.686^{* *} \\
(.319)\end{array}$ & $\begin{array}{l}.943 * * * \\
(.223)\end{array}$ & $\begin{array}{l}1.065 * * * \\
(.336)\end{array}$ \\
\hline $\begin{array}{l}\text { Regional } \\
\text { dummies }\end{array}$ & No & Yes & Yes & Yes & Yes & Yes \\
\hline Period dummies & No & No & Yes & Yes & Yes & Yes \\
\hline Observations & 136 & 136 & 136 & 122 & 122 & 80 \\
\hline R squared & .778 & .835 & .847 & .857 & - & .804 \\
\hline F statistic & 82.59 & 76.61 & 69.09 & 59.09 & 61.04 & 21.69 \\
\hline RMSE & .526 & .458 & .447 & .433 & - & .336 \\
\hline
\end{tabular}


Table 5. Basic results, alternative ("top three") coding

\begin{tabular}{|c|c|c|c|c|c|c|}
\hline Dependent & 1 & 2 & 3 & 4 & 5 & 6 \\
\hline $\begin{array}{l}\text { Average } \\
\text { memberships }\end{array}$ & $\begin{array}{l}5.748^{*} \\
(2.929)\end{array}$ & $\begin{array}{l}4.114^{*} \\
(2.431)\end{array}$ & $\begin{array}{c}3.359 \\
(3.006)\end{array}$ & $\begin{array}{c}4.388 \\
(3.111)\end{array}$ & $\begin{array}{c}4.636 \\
(3.381)\end{array}$ & $\begin{array}{c}.233 \\
(4.424)\end{array}$ \\
\hline Social trust & $\begin{array}{c}43.288 * * * \\
(8.765)\end{array}$ & $\begin{array}{c}32.639 * * * \\
(7.172)\end{array}$ & $\begin{array}{l}34.295 * * * \\
(7.521)\end{array}$ & $\begin{array}{c}39.466 * * * \\
(8.279)\end{array}$ & $\begin{array}{c}38.811 * * * \\
(9.032)\end{array}$ & $\begin{array}{l}35.151 * * * \\
(9.279)\end{array}$ \\
\hline Belief in god & $\begin{array}{c}33.078 * * * \\
(5.157)\end{array}$ & $\begin{array}{c}15.554 * * * \\
(5.232)\end{array}$ & $\begin{array}{c}14.778 * * * \\
(5.159)\end{array}$ & $\begin{array}{l}13.954 * * \\
(5.426)\end{array}$ & $\begin{array}{c}16.722 * * * \\
(5.363)\end{array}$ & $\begin{array}{l}11.707^{*} \\
(6.011)\end{array}$ \\
\hline Divorce rate & $\begin{array}{c}-1.626^{* * *} \\
(.751)\end{array}$ & $\begin{array}{l}-.769 \\
(.755)\end{array}$ & $\begin{array}{l}-.619 \\
(.776)\end{array}$ & $\begin{array}{l}-.856 \\
(.713)\end{array}$ & $\begin{array}{l}-.646 \\
(.802)\end{array}$ & $\begin{array}{l}.666 \\
(.774)\end{array}$ \\
\hline $\begin{array}{l}\text { Unemployment } \\
\text { rate }\end{array}$ & $\begin{array}{c}-.619 * * * \\
(.237)\end{array}$ & $\begin{array}{c}-.630 * * * \\
(.209)\end{array}$ & $\begin{array}{c}-.592 * * * \\
(.225)\end{array}$ & $\begin{array}{c}-.477 * * \\
(.218)\end{array}$ & $\begin{array}{c}-.426^{* *} \\
(.215)\end{array}$ & $\begin{array}{l}-.459^{*} \\
(.272)\end{array}$ \\
\hline $\begin{array}{l}\text { Honest and } \\
\text { efficient gov. }\end{array}$ & $\begin{array}{c}12.133 * * * \\
(1.211)\end{array}$ & $\begin{array}{c}7.266^{* * *} \\
(1.745)\end{array}$ & $\begin{array}{l}7.038 * * * \\
(1.762)\end{array}$ & $\begin{array}{l}4.389 * * \\
(2.096)\end{array}$ & $\begin{array}{l}3.838 * * \\
(1.801)\end{array}$ & $\begin{array}{c}4.055 \\
(2.745)\end{array}$ \\
\hline Postcommunist & & $\begin{array}{c}-16.297 * * * \\
(4.158)\end{array}$ & $\begin{array}{c}-16.916 * * * \\
(4.286)\end{array}$ & $\begin{array}{c}-14.150 * * * \\
(4.316)\end{array}$ & $\begin{array}{c}-15.494 * * * \\
(4.042)\end{array}$ & $\begin{array}{l}-7.148 \\
(6.297)\end{array}$ \\
\hline $\begin{array}{l}\text { Openness to } \\
\text { trade }\end{array}$ & & & & $\begin{array}{l}.063 * * * \\
(.019)\end{array}$ & $\begin{array}{c}.059 * * * \\
(.020)\end{array}$ & $\begin{array}{c}.084 * * * \\
(.021)\end{array}$ \\
\hline $\begin{array}{l}\text { Investment } \\
\text { price level }\end{array}$ & & & & $\begin{array}{c}11.091^{* *} \\
(5.475)\end{array}$ & $\begin{array}{c}12.629^{* *} \\
(4.955)\end{array}$ & $\begin{array}{c}16.801 * * * \\
(6.176)\end{array}$ \\
\hline $\begin{array}{l}\text { Regional } \\
\text { dummies }\end{array}$ & No & Yes & Yes & Yes & Yes & Yes \\
\hline Period dummies & No & No & Yes & Yes & Yes & Yes \\
\hline Observations & 130 & 130 & 130 & 121 & 121 & 80 \\
\hline R squared & .724 & .802 & .807 & .826 & - & .801 \\
\hline F statistic & 84.01 & 79.56 & 61.76 & 46.40 & 33.61 & 22.53 \\
\hline RMSE & 10.315 & 8.835 & 8.843 & 8.339 & - & 7.292 \\
\hline
\end{tabular}


Table 6. Alternative institutional measures, OLS

\begin{tabular}{|c|c|c|c|c|}
\hline & $\begin{array}{l}\text { Average } \\
\text { All }\end{array}$ & $\begin{array}{c}\text { Average } \\
\text { GDP }>8000\end{array}$ & $\begin{array}{c}\text { Top three } \\
\text { All }\end{array}$ & $\begin{array}{c}\text { Top three } \\
\text { GDP }>8000\end{array}$ \\
\hline Legal quality & $\begin{array}{c}.208 * * * \\
(.045)\end{array}$ & $\begin{array}{c}.191 * * * \\
(.045)\end{array}$ & $\begin{array}{c}2.292 * * \\
(.989) \\
\end{array}$ & $\begin{array}{c}2.644 * * \\
(.874)\end{array}$ \\
\hline Observations & 112 & 79 & 111 & 79 \\
\hline R squared & .829 & .816 & .802 & .804 \\
\hline F statistic & 31.39 & 20.67 & 33.88 & 20.27 \\
\hline RMSE & .409 & .322 & 8.048 & 7.191 \\
\hline Gastil index & $\begin{array}{l}-.109^{*} \\
(.059)\end{array}$ & $\begin{array}{c}-.253 * * * \\
(.060)\end{array}$ & $\begin{array}{l}-1.995^{*} \\
(1.097) \\
\end{array}$ & $\begin{array}{c}-4.978 * * * \\
(1.042) \\
\end{array}$ \\
\hline Observations & 121 & 79 & 120 & 79 \\
\hline R squared & .83 & .825 & .821 & .827 \\
\hline F statistic & 50.04 & 30.33 & 46.26 & 34.23 \\
\hline RMSE & .464 & .314 & 8.404 & 6.752 \\
\hline Polity IV index & $\begin{array}{l}.015 \\
(.018)\end{array}$ & $\begin{array}{c}.054 * * * \\
(.014)\end{array}$ & $\begin{array}{l}.506 \\
(.327)\end{array}$ & $\begin{array}{c}1.183 * * * \\
(.258)\end{array}$ \\
\hline Observations & 121 & 79 & 120 & 79 \\
\hline R squared & .828 & .809 & .819 & .819 \\
\hline F statistic & 44.91 & 28.44 & 43.29 & 30.43 \\
\hline RMSE & .473 & .328 & 8.452 & 6.896 \\
\hline $\begin{array}{l}\text { Democratic } \\
\text { process }\end{array}$ & $\begin{array}{c}.475^{* * *} \\
(.131)\end{array}$ & $\begin{array}{c}.871 * * * \\
(.179)\end{array}$ & $\begin{array}{l}5.555^{* *} \\
(2.667)\end{array}$ & $\begin{array}{c}14.989 * * * \\
(5.276)\end{array}$ \\
\hline Observations & 122 & 80 & 121 & 80 \\
\hline R squared & .837 & .798 & .788 & .773 \\
\hline F statistic & 66.76 & 68.27 & 46.66 & 24.90 \\
\hline RMSE & .461 & .338 & 9.151 & 7.714 \\
\hline $\begin{array}{l}\text { Political contraints } \\
\text { III }\end{array}$ & $\begin{array}{c}.391 \\
(.309)\end{array}$ & $\begin{array}{c}.997 * * * \\
(.288)\end{array}$ & $\begin{array}{c}6.824 \\
(5.819)\end{array}$ & $\begin{array}{c}22.898 * * * \\
(6.185)\end{array}$ \\
\hline Observations & 119 & 77 & 118 & 77 \\
\hline $\mathrm{R}$ squared & .827 & .803 & .812 & .818 \\
\hline F statistic & 40.95 & 22.10 & 38.18 & 24.48 \\
\hline RMSE & .476 & .335 & 8.619 & 6.972 \\
\hline $\begin{array}{l}\text { Political contraints } \\
\text { V }\end{array}$ & $\begin{array}{c}.763 * * * \\
(.254)\end{array}$ & $\begin{array}{l}1.227 * * * \\
(.278)\end{array}$ & $\begin{array}{c}11.689 * * \\
(4.999)\end{array}$ & $\begin{array}{c}21.689 * * * \\
(5.698)\end{array}$ \\
\hline Observations & 118 & 77 & 117 & 77 \\
\hline $\mathrm{R}$ squared & .832 & .819 & .815 & .816 \\
\hline F statistic & 49.05 & 27.71 & 37.55 & 30.18 \\
\hline RMSE & .456 & .321 & 8.422 & 6.996 \\
\hline Law and order & $\begin{array}{l}.140 * * \\
(.068)\end{array}$ & $\begin{array}{c}.132 \\
(.079)\end{array}$ & $\begin{array}{c}1.417 \\
(1.269)\end{array}$ & $\begin{array}{c}1.878 \\
(1.629)\end{array}$ \\
\hline Observations & 117 & 77 & 116 & 77 \\
\hline R squared & .823 & .788 & .802 & .792 \\
\hline F statistic & 45.85 & 17.95 & 40.74 & 20.27 \\
\hline RMSE & .461 & .348 & 8.648 & 7.445 \\
\hline
\end{tabular}


Table 7. Which indicators are robust?

\begin{tabular}{lcccc}
\hline & $\begin{array}{c}\text { Average } \\
\text { All }\end{array}$ & $\begin{array}{c}\text { Average } \\
\text { GDP }>8000\end{array}$ & $\begin{array}{c}\text { Top three } \\
\text { All }\end{array}$ & $\begin{array}{c}\text { Top three } \\
\text { GDP }>8000\end{array}$ \\
\hline Legal quality & $7^{*}$ & $7^{*}$ & $7^{*}$ & $5^{*}$ \\
Gastil index & $1^{*}$ & $7^{*}$ & $1^{*}$ & $7^{*}$ \\
Polity IV index & 0 & $4^{*}$ & 0 & $5^{*}$ \\
Honest and efficient gov. & $5^{*}$ & $4^{*}$ & $3^{*}$ & 0 \\
Democratic process & $2^{*}$ & $7^{*}$ & $4^{*}$ & $6^{*}$ \\
Law and order & 2 & 0 & 0 & 0 \\
Political constraints III & 1 & $5^{*}$ & 0 & $5^{*}$ \\
Political constraints V & $4^{*}$ & $7^{*}$ & $3^{*}$ & $7^{*}$ \\
\hline
\end{tabular}

Note: figures are instances in which the indicator remains significant at $\mathrm{p}<.05$ when one other indicator is added. An asterix implies that it is also robust to the inclusion of (log) GDP per capita. 
Table 8 . Testing types of institutions

\begin{tabular}{lcccc}
\hline & Average & Average & Top three & Top three \\
& All & GDP $>8000$ & All & GDP $>8000$ \\
\hline Political factor & -.011 & $.125^{* * *}$ & .878 & $3.112^{* * *}$ \\
& $(.046)$ & $(.034)$ & $(.854)$ & $(.809)$ \\
Economic factor & $.094 * *$ & .077 & .834 & .843 \\
& $(.039)$ & $(.060)$ & $(.755)$ & $(1.092)$ \\
\hline Observations & 109 & 77 & 108 & 77 \\
R squared & 798 & .807 & .791 & .818 \\
F statistic & 26.32 & 28.74 & 27.35 & 33.44 \\
RMSE & .427 & .335 & 8.109 & 7.011 \\
\hline Political factor & -.029 & $.097 * *$ & .684 & $3.199 * * *$ \\
& $(.039)$ & $(.044)$ & $(.870)$ & $(1.113)$ \\
Economic factor & $.113 * * *$ & $(.049)$ & $(.849$ & 1.087 \\
& $(.041)$ & 77 & 109 & $(1.257)$ \\
\hline Observations & 109 & 25.60 & 20.67 & 77 \\
F statistic & 32.02 & & 15.80 \\
\hline Note: robust standard errors in parenthesis; $* * *(* *)[*]$ indicates significance at $\mathrm{p}<.01(\mathrm{p}<.05)[\mathrm{p}<.10] ;$ \\
all regressions include the baseline variables but only estimates of institutional quality are reported. The \\
lower panel reports the robust regression results. & &
\end{tabular}


Table A1. Data sources

\begin{tabular}{|c|c|}
\hline $\begin{array}{l}\text { Life satisfaction, top three } \\
\text { Life satisfaction, average } \\
\text { Average memberships } \\
\text { Social trust } \\
\text { Belief in god }\end{array}$ & World Values Survey (2006) \\
\hline $\begin{array}{l}\text { Divorce rate } \\
\text { Unemployment rate } \\
\text { Postcommunist }\end{array}$ & World Bank (2007) \\
\hline $\begin{array}{l}\text { Openness to trade } \\
\text { Investment price level } \\
\text { GDP per capita }\end{array}$ & Penn World Tables, Mark 6.1 (Heston et al., 2002) \\
\hline Legal quality & The Fraser Institute (Gwartney and Lawson, 2005) \\
\hline Gastil index & Freedom House (2005) \\
\hline Polity IV index & Polity IV (Marshall and Jaggers, 2002) \\
\hline $\begin{array}{l}\text { Honest and efficient } \\
\text { government }\end{array}$ & Helliwell (2006) \\
\hline Democratic process & Helliwell (2006) \\
\hline Law and order & Henisz (2000) \\
\hline Polcon III & Henisz (2002) \\
\hline Polcon V & Henisz (2000) \\
\hline
\end{tabular}


Table A2. Countries included in the study

\begin{tabular}{lll}
\hline Albania & France & Peru \\
Argentina & Georgia & Poland \\
Armenia & Germany & Portugal \\
Australia & Greece & Puerto Rico \\
Austria & Hungary & Romania \\
Belarus & Iceland & Russia \\
Belgium & Ireland & Singapore \\
Brazil & Italy & Slovak Republic \\
Bulgaria & Japan & Slovenia \\
Canada & Korea, South & Spain \\
Chile & Latvia & Sweden \\
China & Lithuania & Switzerland \\
Croatia & Luxembourg & Ukraine \\
Czech Republic & Malta & United Kingdom \\
Denmark & Mexico & United States \\
Dominican Rep & Moldova & Uruguay \\
El Salvador & Netherlands & Venezuela \\
Estonia & New Zealand & \\
Finland & Norway & \\
\hline
\end{tabular}

Note: countries in italics are not included in the sample of countries with a GDP per capita above 8000 USD. 
Table A3. Principal components analysis

\begin{tabular}{lccc}
\hline Variable & Political factor & Economic factor & Uniqueness \\
\hline Honest and efficient gov. & .038 & .829 & .308 \\
Democratic process & .296 & .814 & .231 \\
Legal quality & -.034 & .591 & .572 \\
Gastil index & .909 & -.207 & .123 \\
Polity IV & .925 & .005 & .126 \\
Law and order & .083 & .436 & .556 \\
Polcon III & .447 & .066 & .526 \\
Polcon V & .509 & .199 & .335 \\
\hline Eigenvalue & 3.134 & 1.552 & \\
\hline
\end{tabular}

Note: component loadings have been rotated. 